\title{
Strategic entrepreneurship and performance of Nigerian banks: A quantitative approach
}

\author{
Praise Oluwatoyin Omoshagba, Mercy Modupe Adeyeye, Ademola Samuel Sajuyigbe
}

\section{A B S T R A C T}

Objective: Strategic entrepreneurship provides value that allows companies to compete favourably in the market compared to their competitors, especially in the banking sector, and thus influence their performance. Therefore, this study examined the impact of strategic entrepreneurship on the performance of Nigerian banks.

Research Design \& Methods: A quantitative approach was adopted for the study, which used a post facto study design. The sample size consists of 10 banks listed before 2009 that were only excluded in 2018 with related data. Secondary data collected from annual reports and financial statements of all sample banks over ten years (2010-2019) were analysed. Panel data analysis was used to measure the relationship between independent and dependent variables at $p<0.05$.

Findings: The study demonstrates that strategic dimensions of entrepreneurship (strategic renewal, sustainable innovation, and domain renewal) play a key role in joint and significant organizational performance. It has also been confirmed that strategic renewal independently affects business organizational performance, while domain definition has a positive but minor relevance. However, permanent regeneration has the opposite effect on organizational performance.

Implications \& Recommendations: This finding means that many Nigerian banks have failed to put into practice the knowledge and financial commitment to take advantage of opportunities, which is an important means of strengthening the sector amid the pandemic syndrome and highly turbulent environment. It is therefore imperative that the management of Nigerian banks be financially engaged in formulating innovative strategies and activities.

Contribution \& Value Added: The study has established that strategic entrepreneurship components jointly and independently influence the performance of Nigerian banks. It was also discovered that strategic renewal, sustainable innovation, and domain renewal are strong predictors of banks' performance.

\begin{tabular}{lll}
\hline Article type: & research article & \\
Keywords: & strategic entrepreneurship; strategic renewal; sustained regeneration; domain redefini- \\
JEL codes: & tion; firm performance & \\
\hline \multicolumn{2}{c}{ J64, M10, M14 } & \\
\hline
\end{tabular}

Suggested citation:

Omoshagba, P.O., Adeyeye, M.M., \& Sajuyigbe, A.S. (2021). Strategic entrepreneurship and performance of Nigerianbanks: A Quantitative Approach. International Entrepreneurship Review, 7(2), 21-30. https://doi.org/10.15678/ IER.2021.0702.02

\section{INTRODUCTION}

The pivotal contribution of the banking sector to the nation's economy has been documented and acknowledged by scholars, financial analysts, and economists across the globe. Consumer News and Business Channel (NBC, 2020) recently revealed that the market capitalization of the global banking quarter stood at 7.9 trillion Dollars as of October 2019. It has been estimated that by 2022, the sector is expected to attain 26.5 trillion (Market Screener, 2020). According to the National Bureau of Statistics (2020)'s records, the banking sector contributes $24 \%$ to Nigeria's GDP as of the first quarter of 2020. This development shows that the banking sector is one of the fastest developing sub-sectors in 
the world economy. In line with this perception, Erdal and Ekinci (2013) observe that an effective banking sector constitutes an essential portion of the financial system and thus it is fundamental to achieving sustainable economic growth. Additionally, Naumovska et al. (2015) reiterate that the banking sector has the opportunities to alter useful resource allocation and saving rates with an influence on longterm financial growth. However, the sector combats unhealthy competition challenges, operational and regulatory challenges, and the novel COVID-19 pandemic devastation. Since lethal diseases have been declared by the World Health Organization (WHO) on 11th March 2020, the banking sector has been experiencing dwindling profit. Evidently, IMF (2020) confirms that the sector's income has adversely hit hard by the financial shock of the novel COVID-19 and the sector will remain under stress through 2025. The consequence of this scenario has made many banks in Nigeria opt for the retrenchment of their personnel while others are thinking of mergers and acquisitions.

Strategic entrepreneurship has been documented as construction related to organizational performance and profitability (Adeyeye, 2016; Genç, 2012; Kuratko et al., 2015). Strategic entrepreneurship provides a value that enables companies to compete favorably in a competitive market and thus affect their performance (Kuratko \& Audretsch, 2013;Morris et al., 2012; Postuła \& Majczyk, 2018). It expresses a clear sense of strategic vision, focuses more intensely on goals and specifics, and minimizes competitive disadvantages. In addition, it encourages employees to make decisions by giving those instructions on what to do, when, and how to do it and to help them make the journey easier based on positive decisions. Finally, it provides a detailed assessment of the company's internal and external environment, as well as an effective and efficient way to implement measures that affect the company's organizational performance, especially from the point of view of expanding customer base (Bhatti et al., 2020; Covin \& Miles, 2006; Dyduch, 2019; Hitt et al., 2011;Kuratko, 2013). The strategic dimensions of entrepreneurship such as strategic renewal, sustainable revitalization, and redefined domains are researched very intensively in the academic fields and applied to most organizations to gain competitive advantage in advanced countries (Genc, 2012; Jancenelle et al., 2017; Kuratko \& Morris, 2018; Yiu et al., 2014).

However, little or no research has linked these parameters to institutional performance, particularly in the Nigerian banking sector (Adeyeye, 2016). Therefore, this current study intends to fill this existing gap in the literature by examining the extent to which strategic entrepreneurship dimensions (strategic renewal, sustained regeneration, and domain redefinition) influence organizational performance with specific reference to the Nigerian banking sector.

\section{LITERATURE REVIEW AND HYPOTHESES DEVELOPMENT}

\section{Strategic Renewal}

Strategic renewal is an entrepreneurial strategy phenomenon under which the organization seeks to renew its relationships with its markets or industry competitors by radically changing its competitive model (Jancenelle et al., 2107; Kuratko, 2017; Kuratko, \& Audretsch, 2013). Strategic renewal is viewed as the process, content, and outcome of a firm's freshness or replacement, which has the potential to significantly impact its long-term future. This is a change in the organization (An, et al., 2018; Han \& Park, 2017) in order to change the scope of the business or strategic approach, most often the transformation of organizations through the refinement of those key ideas, which are built (Agarwal \&Helfat, 2009; Balasubrahmanyam, et al., 2012; Corbett et al., 2013; Morris et al., 2012;). This can be discontinued, that is, the continuous effort to change or change the strategic content or the implementation represents a major or sudden change in the strategic content or implementation or enhancement (Mazzei, 2018; Postuła \& Majczyk, 2018; Riviere et al., 2018). Therefore, strategic renewal can occur when a firm develops a "new" strategy and attempts to increase or maintain competition by better executing a specific "pre-existing" strategy and using an environmentally friendly approach for the best performance. In both cases, the internal processes, structures, and/or capabilities of the organization may change. (Riviere et al., 2018; Sáez-Martínez,2011; Yiu, et al. , 2014). According to Klammer et al. (2017), strategic renewal reflects the strategic and organizational change that involves redefining the business concept, restructuring, and introducing system-wide changes. 
Studies carried out by Mohutsiwa (2012), Urban and Wood (2017) and Schmitt et al. (2018) substantiate that strategic renewal enhances firms' performance by increasing their ability to extend firm capabilities and creatively leverage them to add shareholders' value. Similarly, Bierwerth et al., (2015) and Kearney and Morris (2015) reaffirm that self-renewal programs by banks such as self-service, mobile money that redefine or adapt firms' business concepts increase their ability to react faster to threats and opportunities in dynamic industries. In the same direction, Kuratko (2017) confirms that strategic renewal allows a company to adapt its business structure to alter environmental conditions and to react more efficiently to environmental changes. Based on the above empirical studies, the following hypothesis emerged:

H1: There is a significant relationship between strategic renewal and firm performance of the banking sector.

\section{Sustained Regeneration}

Sustained regeneration involves the constant introduction of new products, new services, or access to new markets, creating competitive advantages that differentiate others from others (Morris et al., 2012). This requires innovation, competitive aggression, and a pro-active approach (Chen et al., 2011; Kuratko et al., 2015). It is a frequent and less risky approach to the organization's culture, structure, and systems management. Sustained regeneration seeks to maximize existing human and structural existing organizational resources (Dess et al., 2003), based on the established organizational context. Structures must be flexible and organic to allow them to make quick decisions and make continual innovations (Kuratko \&Morris, 2018; Mazzei, 2018). This method is often used by banks to achieve competitive advantage under short product life cycle conditions and constantly changing technical standards (Dhliwayo, 2014; Kuratko \&Audretsch, 2013), as it is done by automated teller machines (ATMs). Initially, some banks started using it for customers, each bank has ATMs but strategically entrepreneurial banks continue to offer different features and security features that attract customers to the disadvantage of other banks. Thus, it is hypothesized that:

H2: There is a significant relationship between sustained regeneration and firm performance.

\section{Domain Redefinition}

Domain redefinition is the redefining of a firm's existing domain in terms of location or industry to gain a competitive advantage and improve performance. It is the reintegration of an existing product or target market (Kantur, 2016; Kuratko et al, 2015; Kuratko \& Morris, 2018; Mazzei, 2018; Morris et al., 2011). It explores a new market, becoming the first entrant in a new field, to achieve the first proposer (Golder \&Tellis, 1993). For example, banks are usually concentrated in the state capitals of Nigeria, however, Guaranty Trust Bank was one of the first commercial banks to have branches in other cities, with other products not available at other banks at the time. This gave it an edge over others in terms of market share and overall performance. Domain redefinition is the rarest form of corporate strategy, as it is characterized by active creation in the product market and the discovery of unsolicited status (Chen et al., 2011; Covin \& Miles, 1999). This explains what Mintzberg and Westley (1992) calls revolutionary or overlapping strategic redirection (Covin \& Miles, 1999). Research by Chan (2017) and Dikmen(2016) is consistent with previous research that domain redefinition improves organizational performance. Therefore, it hypothesized that:

H3: There is a significant relationship between domain redefinition and firm performance.

\section{RESEARCH METHODOLOGY}

This study used a quantitative approach using an ex post facto study design with a focus on examining panel data. It is a statistical analysis of data sets of multiple observations for each sample unit at different points in time, as is most appropriate for the study in question. According to a report by NBC (2020), Nigeria's banks consisted of the 22 banks included in the list. The sample size consists of 10 
banks listed prior to 2009 and not delisted before 2019 was used to provide an adequate time frame to establish the cause and effect of the incident. Secondary data was used from the annual reports and financial statements of all banks in the sample for ten years (2010-2019) each, as reported by the Nigerian Stock Exchange (NSE). The NSE data has been thoroughly reviewed by various analysts to be reliable, objective, and research-accurate. A panel data analysis was used to measure the relationship between the independent and dependent variables. A fixed-effects model test was performed to show the relationship between the dependent and independent variables within an organization, as each organization has its own individual characteristics that may or may not affect the variables. The random-effects model helped to include time-independent variables, and the Hausman test was used to decide which was more appropriate: a fixed or random effect for the study.

\section{Model Specification}

This model is built on the Dynamic Capabilities Theory adapted from the work of Teece (2017), and Zhou et al.(2019). The study developed two models to measures the dependent variable, Organizational Performance by using profit level. Consequently, the independent variable (strategic entrepreneurship) utilized three of the measures established in prior literature (Kuratko et al., 2015; Morris et al., 2012), the strategic renewal (amount spent on the formulation of strategy), sustained regeneration (innovative activities), and domain redefinition (the cost of investing in new markets) with firm age as a control variable (Bjornskov \& Foss, 2013). The study was carried out using multiple linear regressions, the fixed-effect model, the random effect model, and the Hausman test.

\section{RESULTS AND DISCUSSION}

This section quantitatively describes the basic features of the data for the studies. It consists of the summaries of the sample under study.Table 1 presents the descriptive statistics of the variables in the data analysis that cut across the ten (10) listed commercial banks for a period of ten years. The result of Profit $(P R)$, Strategic renewal, Sustained regeneration, domain redefinition, and Firm Age (FA) are 23.663, $24.154,20.931,23.062$, and 24.1 respectively, all in millions of naira. These values fell between the minimum and maximum values of each of the variables. This indicated that the data are normally distributed. The standard deviations of $1.358,0.856,1.537,2.504$, and 12.797 for Profit, Strategic renewal, Sustained regeneration, domain redefinition, and Firm Age (FA) respectively, showed that the deviation from the mean value is marginal or insignificant which indicated that there was less fluctuation in the data suggesting a stable performance in the activities of the banks in the study. The results of the Skewness for Profits, Strategic renewal, Sustained regeneration, and Domain redefinition are $-0.189,-0.505,-0.103$, and -.079 respectively, showing that they are skewed to the left which indicated that the distribution is clustered around the maximum value. While the result of Firm age is skewed to the right with a value of 0.973 , a positive mean value indicated that the distribution of the study is good.

Table 1. Descriptive statistics of the variables

\begin{tabular}{|l|l|l|l|l|l|l|l|}
\hline \multicolumn{1}{|c|}{ Variables } & Observations & Mean & $\begin{array}{l}\text { Standard } \\
\text { Deviation }\end{array}$ & Minimum & Maximum & Skewness & Kurtosis \\
\hline Profit & 100 & 23.663 & 1.358 & 20.596 & 26.380 & -0.189 & 2.081 \\
\hline Strategic Renewal & 100 & 24.154 & 0.856 & 21.725 & 25.620 & -0.505 & 2.485 \\
\hline Sustained Regeneration & 100 & 20.931 & 1.537 & 17.182 & 23.614 & -0.103 & 2.453 \\
\hline Domain Redefinition & 100 & 23.062 & 2.504 & 16.522 & 27.398 & -1.079 & 4.111 \\
\hline Firm Age & 100 & 24.1 & 12.796 & 12 & 48 & 0.973 & 2.527 \\
\hline
\end{tabular}

Source: own study.

\section{Heteroskedasticity Test}

The difference in error from registration depends on the values of the independent variable, and a heteroskedasticity test was performed to determine the suitability of the regression model. The presence of heterosexuality is evident when the probability of Chi-Square is less than $5 \%$ and may affect the statistical 
influences. The results of the heteroskedasticity performed with the corporate strategy variable show that there is no heteroskedasticity. For example, the probability of Chi-square in the first model was 0.95955 while the probability of Chi-square in the second model was 0.4296 . Therefore, the study does not require the use of Robust Ordinary Least Square for the variables predicted to be variable.

\section{Hausman Specification Test}

The Hausman test was performed to determine if the General Leased Square (GLS) regression fixed effect ( $\mathrm{FE}$ ) or random effect (RE) method was appropriate for regression. - The result of the Chi-Square coefficient was 28.92 and was significant at $P<0.05$. When the P-value was less than 0.05 , it thus inferred that the more appropriate model for the analysis was the fixed effect model. The study, therefore, utilized the fixed effect model. Table 2 presents the regression analysis of the model, which showed the relationship between the dependent (profit), and the independent variables (strategic renewal, sustained regeneration, and domain redefinition). An R-square value of 0.3322 indicates that the independent variables in the study accounted for $33 \%$ of the total variance of the dependent variable, while the remaining $67 \%$ of the variance in the dependent variable was explained by the variables that were not included in the study. This means that the strategic dimensions of entrepreneurship add up to $33 \%$ of overall corporate performance. The results showed that the model fit well with the study; this is indicated by the result of the $F$ value of 14.42 and is statistically significant at $P<0.05$. It is necessary to note that firm age was omitted in the regression result as it did not have an effect on the entrepreneurial performance of the commercial banks.

Table 2. Results of the regression analysis

\begin{tabular}{|l|c|c|}
\hline \multicolumn{1}{|c|}{ Variables } & Model (Profit ) & p-value \\
\hline Constant & -12.54703 & 0.000 \\
\hline Strategic Renewal & 1.627 & 0.000 \\
& $(4.76)^{*}$ & 0.000 \\
\hline Sustained Regeneration & -0.229 & 0.786 \\
& $(-2.63)^{*}$ & \\
\hline Domain Redefinition & 0.73 & - \\
\hline R Square & $(0.27)$ & - \\
\hline F-value & 0.3322 & - \\
\hline
\end{tabular}

Note: ${ }^{*} p<0.05$.

Source: own study.

Table 2 reveals the result of the regression coefficient of 1.627, which indicates a positive relationship between strategic renewal and organizational performance. This means that a unit increase in strategy will increase the profits of the banks by 1.627. Additionally, the result is statistically significant with a $p$-value of 0.000 , the value of which is significant at $P<0.05$. These findings suggest that the more banks come up with new and improved strategies, the more they will be able to position themselves in the market, leading to greater performance and profits, in the long run, thus supporting the theory of dynamic capabilities. This is the theoretical basis of the study. Dynamically, banks invest more in strategic innovation, their performance, and it becomes more competitive. Corporate entities such as banks must be subjected to regular scrutiny and adapt to their corporate concept and be able to innovate to avoid bankruptcy. It is believed that firms must continually combine, build and redesign external and internal competition to address changes in the dynamic market environment. It was Sáez-Martínez (2011), Bierwerth et al. (2015), Dai et al. (2015), and Shu et al.(2019), who expressed that strategic innovation has a positive and statistically significant relationship with entrepreneurial performance. Hence, the $\mathrm{H} 1$ is accepted.

A regression coefficient of -0.229 was also detected, indicating a negative and significant relationship between continuous improvement and organizational performance. This negative relationship could mean that the banks did not carry out appropriate new activities. This finding differs from previous studies outside of Nigeria and has not supported Dai et al. (2015), the findings of Kuratko and Morris (2018), 
Mazzei (2018), and Tuzovic et al. (2018) that are continuous innovations in the form of new products and services required for a better performance of the organization. This could possibly be due to insufficient investment in innovative resources, such as human resources, that will promote innovative activities, especially in most banks, where the attitude towards employment of employees is slow due to challenges, especially in the sectors financial Most banks in Nigeria employ contract employees who lack job security and are poorly paid, leading to high employee turnover rates. This in no way affects the quality of hired employees as dynamic capabilities, innovative employees will go to other areas for fulfilment. Finally, investment in organizational resources, including employee motivation, is necessary to increase employee commitment to continuous improvement. Therefore, the $\mathrm{H} 2$ is rejected.

The model also revealed a positive but insignificant relationship between domain redefinition and organizational performance, with a regression coefficient result of 0.073 , so that a unit increase in domain redistribution would lead to a 0.073 increase in total assets of the banks. Also, it shows a pvalue of 0.786 which is statistically insignificant at $P>0.05$. The findings of this study may be the result of a lack of interest in spending on dynamic opportunities, staying active, and taking risks as pioneers in other fields. This could point to Brand Finance (2020) which claims that no Nigerian bank has been included in the top 10 banks in Africa. This finding seems unique because it contradicts Bogner and Petricevic(2015) finding that domain redefinition requires the deployment of dynamic capabilities in new records, leading to increased organizational productivity. - Most commercial banks in Nigeria see a threat, especially as new markets are entering, possibly due to the increased risk of insecurity in the north, which has forced some banks to abandon such an environment altogether. And due to repeated bank robberies in Nigeria. Hence, the $\mathrm{H}_{3}$ is partially accepted.

\section{CONCLUSIONS}

This study examines the impact of strategic entrepreneurship on the performance of Nigerian banks. They found that aspects of strategic entrepreneurship (strategic renewal, sustained regeneration, and domain redefinition) collectively contribute to the performance of an organization. It was also confirmed that strategic renewal independently influences organizational performance, while domain redefinition has a positive relationship but insignificant. However, sustained regeneration has an inverse influence on organizational performance. Deduction to be made from this finding is that many Nigerian banks have not put in place the necessary knowledge and financial commitment for the exploitation of opportunities, which is an essential tool for them to wax stronger in the midst of pandemic syndrome and in a highly turbulent environment. This implies that strategic entrepreneurship is still at the infancy stage in the Nigerian banking sector. It is imperative, therefore, for the management of Nigerian banks to be financially committed to strategy formulation, innovative activities, and investment in human resources.

\section{Managerial Implication}

The study reveals to the Nigerian banking administration the important role of business strategy in verifying the sustainability of the sector in an unpredictable, dynamic and competitive business environment. Investing in organizational resources such as staff motivation, willingness to spend on dynamic skills, proactivity and risk-taking is an indication of the survival business strategies of Nigerian banks. This implies that the sector should be regularly subjected for review and be flexible in terms of their organizational concept, financially committed to strategy formulation, innovative activities, and investment in human resources to be able to become innovative to avoid liquidation.

\section{Limitations and Recommendations for Further Research}

This study has several limitations that can be researched for future studies. The first limitation is that the study was limited to the banking sector which can be extended to other sectors such as the manufacturing sector, telecommunication sector, education sector etc. Secondly, the study used only questionnaires whereas, interviews can be included for further studies. Thirdly, the study used only a quantitative approach, meanwhile, both qualitative and quantitative techniques can be used in future studies. 


\section{REFERENCES}

Adeyeye, M.M. (2016).Corporate Entrepreneurship as a Paradigm for Successful Competition and Growth. Journal of Research in Management and Social Sciences, 2 (2),1-8.

Agarwal, R., \& Helfat, C. E. (2009). Strategic Renewal of Organizations. Organization Science Journal, 20(2), 281-293.

An, W., Zhao, X., Cao, Z., Zhang, J., \& Liu, H. (2018). How Bricolage Drives Corporate Entrepreneurship: The Roles of Opportunity Identification and Learning Orientation. Journal of Product Innovation Management, 35(1), 49-65.

Balasubrahmanyam, S., Kaipa, P., \&Akhilesh, K. B. (2012). The Impact of a Firm's Financial Flexibility on Its Strategic Renewal: Key Concepts with Evidential Support from Businesses across Industries. Global Journal of Flexible Systems Management, 13(3), 165-175.

Bhatti, A., Rehman, S. U., \&Rumman, J. (2020). Organizational capabilities mediates between organizational culture, entrepreneurial orientation, and organizational performance of SMEs in Pakistan. Entrepreneurial Business and Economics Review,8(4), 85-103. https://doi.org/10.15678/EBER.2020.080405

Bierwerth, M., Schwens, C., Isidor, R., \& Kabst, R. (2015). Corporate Entrepreneurship and Performance: A MetaAnalysis.Small Business Economics,45(2), 255-278.

Bjørnskov, C., \& Foss, N. (2013). How strategic entrepreneurship and the institutional context drive economic growth. Strategic Entrepreneurship Journal, 7(1), 50-69.

Bogner, W. C., \& Petricevic, O. (2015). Corporate Ventures and Knowledge. Wiley Encyclopaedia of Management, 1-5.

Chan, B. H. (2017). How to build new competitive competencies in transaction banking. Journal of Digital Banking, 2(1), 13-21.

Chen, G., Du, H., \& Chen, Y. (2011). Research on Entrepreneurial Orientation and Entrepreneurial Behavior: An Empirical Study. Proceedings of 2011 International Conference on Management and Service Science, 1-3.

Corbett, A., Covin, G.J., O'Connor, G.C.,\& Tucci, C.L. (2013).Corporate Entrepreneurship: State-Of-The-Art, Research and Future Agenda. Journal of Innovation and Management, 30(5), 812-820.

Covin, J., \& Miles, M. (1999). Corporate entrepreneurship and the pursuit of competitive advantage. Entrepreneurship Theory and Practice, 23, 47-63.

Covin, J., \& Miles, M (2006). Corporate Entrepreneurship and the Pursuit of Competitive Advantage. Harvard University Press.

Dai, W.D., Mao, Z. E., Zhao, X. R., \& Mattila, A. S. (2015). How Does Social Capital Influence The Hospitality Firm's Financial Performance? The Moderating Role of Entrepreneurial Activities. International Journal of Hospitality Management,51, 42-55

Dess, G.G., Ireland, R. D., Zahra, S. A., Floyd, S.W., Janney, J. J., \& Lane, P. J. (2003). Emerging Issues in Corporate Entrepreneurship. Journal of Management, 29(3), 351-378.

Dikmen, C. (2016). A Field Application Measuring Healthcare Employees' Perceptions toward Corporate Entrepreneurship. International Journal of Health Administration and Education Congress (Sanitas Magisterium), 1, 23-40.

Dhliwayo, S. (2014). Entrepreneurship and competitive strategy: An integrative approach. The Journal of Entrepreneurship, 23(1), 115-135.

Dyduch, W. (2019). Entrepreneurial Strategy Stimulating Value Creation: Conceptual Findings and Some Empirical Tests. Entrepreneurial Business and Economics Review, 7(3), 65-82.https://doi.org/10.15678/EBER.2019.070304

Erdal, H. I., \& Ekinci, A. (2013). A Comparison of Various Artificial Intelligence Methods in the Prediction of Bank Failures. Computational Economics, 42(2), 199-215.

Genç, K. Y. (2012). The Response of the Entrepreneurship to the Changing Business Environment: Strategic Entrepreneurship. International Journal of Economic and Administrative Studies, 5(9), 71-83.

Golder, P.N.,\&Tellis, G.J. (1993) Pioneer Advantage: Marketing Logic or Marketing Legend. Journal of Marketing Research, 30, 158-170.

Han, J., \& Park, C.M. (2017). Case Study on Adoption of New Technology for Innovation: Perspective of Institutional And Corporate Entrepreneurship. Asia Pacific Journal of Innovation and Entrepreneurship, 11(2), 144-158.

Hitt, M.A., Ireland, R. D., Sirmon, D. G., \& Trahms, C.A. (2011). Strategic Entrepreneurship: Creating Value for Individuals, Organizations, and Society. Academy Of Management Perspectives, 25(2), 57-75. 
IMF (2020). Policy Responses to COVID-19. Available at https://www.imf.org/en/Topics/imf-and-covid19/PolicyResponses-to-COVID-19

Jancenelle, V. E., Storrud-Barnes, S., \&Javalgi, R. R. G. (2017). Corporate Entrepreneurship and Market Performance: A Content Analysis of Earnings Conference Calls. Management Research Review,40(3), 352-367.

Kantur, D. (2016). Strategic Entrepreneurship: Mediating the Entrepreneurial Orientation-Performance Link. Management Decision,54(1), 24-43.

Kearney, C., \& Morris, M. H. (2015). Strategic Renewal as a Mediator of Environmental Effects on Public Sector Performance. Small Business Economics,45(2), 425-445.

Klammer, A., Gueldenberg, S., Kraus, S., \&O'Dwyer, M. (2017). To Change or Not to Change-Antecedents and Outcomes of Strategic Renewal in SMEs. International Entrepreneurship and Management Journal,13(3), 739-756.

Kuratko, D. F. (2013). Entrepreneurship: Theory, Process, and Practice. South Western Publishers.

Kuratko, D. F. (2017). Corporate Entrepreneurship 2.0: Research Development and Future Directions. Foundations and Trends in Entrepreneurship,13(6), 441-490.

Kuratko, D. F., \& Audretsch, D. B. (2013). Clarifying the Domains of Corporate Entrepreneurship. International Entrepreneurship and Management Journal, 9(3), 323-335.

Kuratko, D. F., Hornsby, J. S., \& Hayton, J. (2015). Corporate Entrepreneurship: The Innovative Challenge for a New Global Economic Reality.Small Business Economics,45(2), 245-253.

Kuratko, D. F., \& Morris, M. H. (2018). Corporate Entrepreneurship: A Critical Challenge for Educators and Researchers. Entrepreneurship Education and Pedagogy,1(1), 42-60.

List of banks in Nigeria by CBN (2020). Google.com. Retrieved 28 September 2020, from https://www.google.com/search?q=list+of+banks+in+nigeria+by+cbn\&rlz=1C1CHWL_enNG856NG856\&oq $=$ list+of+banks+in+nigeria+by+cbn\&aqs=chrome.69i57j013.26382j0j7\&sourceid=chrome\&ie=UTF-8

Market Screener (2020). 2019 Global Financial Services Market research Reports \& Industry Analysis. Retrieved fromhttps://www.marketscreener.com/quote/stock/INDUSTRIAL-AND-COMMERCIAL-6499173/news/ on 5 January 2021.

Mazzei, M.J. (2018). Strategic Entrepreneurship: Content, Process, Context, and Outcomes. International Entrepreneurship and Management Journal,14(3), 657-670.

Mintzberg, H., \& Westley, F. (1992). Cycles of Organizational Change. Strategic Management Journal,13, 39-59.

Mohutsiwa, M. (2012). Strategic Entrepreneurship and Performance of Small and Medium Enterprises in South Africa (Doctoral Dissertation). University of Witwatersrand, Johannesburg.

Morris, M. H., Kuratko, D. F.,\& Covin, J. G. (2012). Corporate Entrepreneurship and Innovation. South-Western.

National Bureau of Statistics (2020). Selected Banking Sector Data Q3 2020. National Bureau of Statistics, Abuja.

Naumovska, E., Jovanovski, K., \& Gockov., G. (2015). The Influence of the Banking Sector

Functions on Economic Activity in Macedonia. Scientific Annals of the Alexandruloan Cuza University of Iaşi Economic Sciences, 62 (2), 207-220.

NBC (2020). Global Stock Markets Gained 17 Trillion Dollars in value in 2019. Retrieved from https://www.cnbc.com/2019/12/24/global-stock-markets-gained-17-trillion-in-value-in-2019.html on 5 January 2021.

Postuła, A., \& Majczyk, J. (2018). Managers and Leaders in Need of Entrepreneurial Competences. Entrepreneurial Business and Economics Review, 6(1), 91-103. https://doi.org/10.15678/EBER.2018.060105

Riviere, M., Suder, G., \& Bass, A.E. (2018). Exploring the Role of Internationalization Knowledge In Fostering Strategic Renewal: A Dynamic Capabilities Perspective. International Business Review,27(1), 66-77.

Sáez-Martínez, F.J. (2011). Strategic Renewal, Cooperation, and Performance: A Contingency Approach. Journal of Management and Strategy,2(4), 43-55.

Schmitt, A., Raisch, S., \& Volberda, H. W. (2018). Strategic Renewal: Past Research, Theoretical Tensions and Future Challenges. International Journal of Management Reviews, 20(1), 81-98.

Shu, C., De Clercq, D., Zhou, Y., \& Liu, C. (2019). Government Institutional Support, Entrepreneurial Orientation, Strategic Renewal, And Firm Performance in Transitional China. International Journal of Entrepreneurial Behaviour \& Research, 25(3), 433-456.

Teece, D. J. (2007). Explicating dynamic capabilities: The nature and micro-foundations of (sustainable) enterprise performance. Strategic Management Journal, 28(13), 1319-1350. 
Tuzovic, S., Wirtz, J., \& Heracleous, L. (2018). How Do Innovators Stay Innovative? A Longitudinal Case Analysis. Journal of Services Marketing, 32(1), 34-45.

Urban, B., \& Wood, E. (2017). The Innovating Firm as Corporate Entrepreneurship. European Journal of Innovation Management, 20(4), 534-556.

Zhou, S.S., Zhou, A. J., Feng, J., \& Jiang, S. (2019). Dynamic Capabilities and Organizational Performance: The Mediating Role of Innovation. Journal of Management \& Organization, 25(5), 731-747.

Yiu, D.W., Hoskisson, R. E., Bruton, G. D., \& Lu, Y. (2014). Dueling Institutional Logics and the Effect on Strategic Entrepreneurship in Chinese Business Groups. Strategic Entrepreneurship Journal, 8(3), 195-213. 


\section{Authors}

All the authors have equally prepared the conceptualization, introduction, material and methods, literature review and theory development, discussion and conclusion sections.

\section{Praise Oluwatoyin Omoshagba}

Post-Graduate Student at the Federal University of Technology, Minna (Nigeria). Her research interests include strategic entrepreneurship, small businesses, social entrepreneurship and sustainable entrepreneurship. She has published many articles in both local and international journals.

Correspondence to: Ms. Praise Oluwatoyin Omoshagba, Department of Entrepreneurship and Business Studies, Federal University of Technology, Minna, Nigeria, e-mail: omoshagbatoyin@gmail.com

ORCID (1) http://orcid.org/0000-0003-3262-7919

\section{Mercy ModupeAdeyeye}

PhD in entrepreneurship (2013, University of Essex, UK). Associate Professor in the Department of Entrepreneurship and Business Studies, Federal University of Technology, Minna (Nigeria). Her research interest includes social entrepreneurship, strategic entrepreneurship, developing economies and small and mediumsized enterprises. She has published many journal articles to her credit. A team leader in the SDG groups 1 and 5 (no poverty and gender equality) groups.

Correspondence to: Prof. Mercy Modupe Adeyeye, PhD, Department of Entrepreneurship and Business Studies, Federal University of Technology, Minna, Nigeria, e-mail: memoade4real@yahoo.com

ORCID iㅏ http://orcid.org/0000-0001-9644-9811

\section{Ademola SamuelSajuyigbe}

PhD in management, A lecturer and the secretary of SDG-1 (No Poverty Research Group) at Landmark University in Omu-Aran (Nigeria). His research interests include social entrepreneurship, strategic entrepreneurship, rural entrepreneurship, human resources, and finance. He has published over forty journal publication articles to his credit. He has won TETFUND research grants in Nigeria and he was also honoured by African - Asian Journal of Rural Development Organization in India for a research carried out on rural entrepreneurship development in Nigeria.

Correspondence to: Dr. Ademola Samuel Sajuyigbe, Department of Business studies, Landmark University, Omu-Aran, Nigeria, e-mail: sajuyigbeademola@yahoo.com

ORCID (1) http://orcid.org/0000-0001-6120-6908

\section{Acknowledgements and Financial Disclosure}

The authors would like to thank all of our colleagues in the department for their useful comments, which allowed to increase the value of this article.

\section{Conflict of Interest}

The authors have stated that no contending issue in respect to the authorship and publication of this valuable article is allowed.

\section{Copyright and License}

This article is published under the terms of the Creative Commons

Attribution - NoDerivs (CC BY-ND 4.0) License

http://creativecommons.org/licenses/by-nd/4.0/ 